\title{
Growth Performance and Instability Analysis of Rabi Maize in Banswara District of Rajasthan
}

\author{
Urmila, Latika Sharma and Deepali* \\ Department of Agricultural Economics and Management, MPUAT, \\ Udaipur, (Rajasthan), India \\ *Corresponding author
}

\begin{abstract}
A B S T R A C T
Keywords

Rabi maize, Banswara, area, production, Productivity, Compound annual growth rate, Instability etc

Article Info

Accepted:

07 August 2020

Available Online:

10 September 2020

The present investigation aimed to examine the growth performance and instability analysis of rabi maize in Banswara district of Rajasthan was conducted during 2017-18. The study was based on time series data collected from 2007-08 to 2017-18. The results of the study revealed that among the eleven tehsils of Banswara district, Bagidora emerged as important one because the growth rates for area, production and yield of rabi maize were found significantly highest. Area under the crop observed positive trend for all the tehsils of Banswara except for Sajjangarh and Gangadtalai. Similarly, the compound growth rate for production of rabi maize in all tehsils of Banswara had been positive except for Gangadtalai. Whereas, compound growth rates for yield of rabi maize were observed to be positive in all the tehsils for the period under study. Besides this, high instability had been reported in area, production and yield of rabi maize in the district. Garhi tehsil had recorded the highest instability in the crop area, production as well as yield as compared to other tehsils. The total yield of rabi maize was found to contribute more in production as compared to the total area. But overall positive growth rates in area, production and productivity of rabi maize indicated that environmental factors were in support of increased production of rabi maize in Banswara district.
\end{abstract}

\section{Introduction}

Maize (Zea mays L.) is the world's secondlargest cereal crop in terms of acreage and has wider adaptability to varying agro-climatic conditions. It is the third most vital food crop in India after rice and wheat. The crop has been adopted in different seasons and in different regions. Globally, it occupies an area of 197 million hectare, wherein India ranks fourth with an area of 9.2 million hectare under maize production (FAO, Statistical pocketbook, 2019). Global maize production in 2018-19 has reached around 1135 million MT, where US was the leading producer, led by China, accounting for about 32.69 per cent and 22.83 per cent of global production, respectively. India ranks fifth, with a quantity of 27 million MT (2018-19) contributing just 2.53 per cent of the production. The crop accounts for 9.55 per cent of the total foodgrain production and 11 per cent of the 
total cereal production in India (Directorate of Economics and Statistics, 2018-19). Around 15 million farmers are engaged in maize cultivation and it generates employment for more than 650 million person-days at farming and its related business ecosystem levels (Maize Vision 2022 Report, 2018). Among the various states, Karnataka is India's leading maize producer (3.73 million tonnes) having a share of 14 per cent in India's total maize production followed by Madhya Pradesh (3.68 million tonnes) and Bihar (3.02 million tonnes) which contributes 13.5 per cent and 11.69 per cent, respectively. Maharashtra, Madhya Pradesh, Tamil Nadu, Andhra Pradesh, Rajasthan and Uttar Pradesh are other major maize producing states of India (Ministry of Agriculture \& Farmers Welfare, GOI, 2019).

Maize has three growing seasons in India, namely kharif, rabi and spring. Kharif is the most important season covering around 80 per cent of the total area followed by rabi season that covers 15 per cent of total area of maize in India. Out of the total production, rabi maize was grown on an area of 1.65 million hectare with the grain production of 6.76 million tonnes and average productivity of 4.09 tonnes per hectare and kharif maize was grown on an area of 7.42 million hectare with the grain production of 17.07 million tonnes and an average productivity of 2.30 tonnes per hectare (Agricultural Statistics at a Glance, 2018). The major states producing kharif maize in India are Karnataka, Madhya Pradesh, Tamil Nadu, Maharashtra, Telangana, UP \& Rajasthan; with Karnataka being the leading producer. Whereas Bihar, Andhra Pradesh, Tamil Nadu and Rajasthan are major rabi maize producing states. Bihar ranks first in the production of rabi maize covering an area of 282 thousand hectares with the grain production of around 2.09 million tonnes and an average productivity of 7.42 thousand $\mathrm{Kg}$ per hectare (Directorate of
Economics and Statistics, Government of Bihar, 2018-19).

Rajasthan ranks second in terms of area and fifth in terms of production. The state accounts for 9.31 per cent of the total area and 7.27 per cent of the total production of maize in India. Maize contributes 8.59 per cent of the total food grains production and 14.06 per cent of total cereal production in the state. The crop is being cultivated in 857 thousand hectare area with total production of 1.98 million tonnes and productivity of 2.28 thousand $\mathrm{Kg}$ per hectare in the year 2018-19. Out of this; Rabi, kharif and summer maize were grown in an area of 12 thousand hectares, 844 thousand hectares and 8 hectares, respectively with the grain production of 66 thousand tonnes, 1.89 million tonnes and 29 tonnes, respectively and average productivity of 5.37 thousand $\mathrm{Kg}$ per hectare, 2.24 thousand $\mathrm{Kg}$ per hectare and 3.62 thousand $\mathrm{Kg}$ per hectare, respectively (Department of Agriculture, Government of Rajasthan, 2019-20). Rabi maize is mainly grown in Southern parts of Rajasthan. Major districts producing rabi maize are Dungarpur, Banswara, Pratapgarh, Chittorgarh and Jalore. It accounts for 1.4 per cent of total area and 3.33 per cent of total production of maize in Rajasthan.

Banswara ranks first in terms of both area and production under rabi maize where it is grown in an area of 11.9 thousand hectares with a production and productivity of 65.8 thousand MT and 5.7 tonnes per hectare respectively (Land Revenue Department, Banswara, 2018-19). This is especially because the district qualifies the climatic requirements for Rabi maize cultivation as winter season remain frost free and temperature usually does not fall below $13^{\circ} \mathrm{C}$. This climatic suitability coupled with emerging immense irrigation capabilities due to "Mahi Bajaj Sagar Project" provides bright 
future for rabi maize cultivation in Banswara district. It is a great source of income and nutrition for the tribal people of the area. Hence, Banswara district was purposively selected for the study. Many studies have been carried out before now to examine the growth and instability in different parameters (area, production and productivity) of major agricultural crops (maize, rice, wheat etc.) at all India level (Sahu and Mishra, 2014; Reddy et al., 2015; Ayalew and Sekar, 2016; Eswaran and Revathi, 2017; Jain, 2018; Dey et al., 2020) and also for different states like Bihar (Singh and Ranjan, 1998), Karnataka (Acharya et al., 2012), Jammu and Kashmir (Kachroo et al., 2013) and Odisha (Paltasingh and Goyari, 2013). However, no such recent detailed studies are available for rabi maize in the context of Rajasthan. Also, the production of rabi maize is increasing continuously in the district. A high growth rate and low instability in production are prerequisites for sustainable agricultural performance and has serious implications for policy makers. It was with this context, the trends and instability of area, production and productivity of rabi maize were studied in Banswara district of Rajasthan.

\section{Materials and Methods}

The present study was entirely based on secondary data. Banswara district was purposively selected due to its dominance in area under rabi maize in the state. The analysis was conducted for Banswara district as a whole and also for all the eleven tehsils of the district. Tehsils of Banswara district are Banswara, Bagidora, Ghatol, Garhi, Kushalgarh, Gangadtalai, Aanadpuri, Chotisarvan, Ganoda, Abapura and Sajjangarh. The time series data on area, production and productivity of rabi maize was collected from the land revenue department of Banswara for a period of eleven years from 2007-08 to 2017-18. The compound annual growth rates and instability analysis were computed by employing the following formulae:

\section{Compound growth rate}

By fitting the exponential functions to the figures of area, production and productivity for the period under study, the compound growth rates were computed. For this following form of exponential function was used:

$$
\mathrm{Y}_{\mathrm{t}}=\mathrm{Y}_{0}(1+\mathrm{r})^{\mathrm{t}}
$$

Where,

$Y_{t}=$ Area, Production and Yield of crops in $t^{\text {th }}$ year

$\mathrm{Y}_{0}=$ Area, Production and Yield in initial year

$\mathrm{r}=$ Compound growth rate

$\mathrm{t}=1,2,3 \ldots \ldots$.years.

The log transformation of above equation becomes

$\log Y_{t}=\log Y_{0}+t \log (1+r)$

Assuming $\log \mathrm{Y}_{0}=\log \mathrm{a}$ and $\log (1+\mathrm{r})=\mathrm{b}$, the same expression could be put as:

$$
\log Y_{t}=\log a+b t
$$

This is same as the log-linear form of the exponential function. From this log-linear form, CAGR is worked out as follows by differentiating it with reference to ' $t$ '

$$
\mathrm{d}\left(\log \mathrm{Y}_{\mathrm{t}}\right) / \mathrm{dt}=\mathrm{b}
$$

But the estimate of ' $b$ ' in the log-linear function is in semi-log term. Therefore, to convert it into original form of $\mathrm{Y}_{t}$ following transformation is done: 
Since, $b=\log (1+r)$

Antilog (b) $=1+\mathrm{r}$

$r=($ antilog $b)-1$

CAGR in percentage $=[($ antilog $b)-1] \times 100$

In order to calculate the instability in area, production and productivity of rabi maize in the study region, following formulae were used:

\section{Instability of rabi maize}

$$
\mathrm{I}={ }^{\frac{S D}{A M}} \times 100
$$

Where;

$\mathrm{I}=$ Instability index (C.V.)

$\mathrm{SD}=$ Standard deviation of area, production and yield of crop

$\mathrm{AM}=$ Arithmetic mean of area, production and yield of crop

\section{Results and Discussion}

Area and production of an agricultural crop is influenced by technological as well as policy factors. Therefore, it is meaningful to measure the growth behavior and extent of inter year instability in area, production and yield of such commodities. The growth in production is the resultant effect of growth in area as well as growth in yield. The extent of instability indicates the magnitude of risk associated with such production activity. The growth rate and instability of rabi maize in Banswara district were analyzed in terms of area, production and yield.

\section{Compound Growth Rate of Area Under rabi Maize in Banswara District of Rajasthan}

Tehsil-wise compound growth rate of area under rabi maize for the period 2007-08 to
2017-18 has been presented in Table 1. The compound growth rate of area under rabi maize was found to be positive except in two tehsils of Banswara (Sajjangarh and Gangadtalai) over the time span of 11 years. The highest growth rate of area under rabi maize cultivation was found in Bagidora tehsil (23.80 per cent per annum). Similarly, the area under rabi maize in other tehsils had also increased during the study period. This is mainly because the district has favourable climatic conditions for growing maize during rabi season since the temperature doesn't dip beyond a certain level, On the other hand, the growth rate of rabi maize in Gangadtalai and Sajjangarh tehsils had declined at a rate of 10.34 and 5.00 per cent per annum, respectively. The probable reason behind this is that these two tehsils fall under the noncommand area in the district. Due to this, they get very little or no access to the water facility from Mahi Bajaj Sagar dam which is built across the Mahi River in the district. Moreover, the rabi maize crop is usually of 117 days and is being harvested upto MarchApril. Due to this, the irrigation requirement of the crop doesn't get fulfilled adequately in these two tehsils.

The compound growth rate of area under rabi maize in Garhi, Banswara, Ghatol, Kushalgarh, Anandpuri, Chhotisarvan, Aabapura and Ganoda had been increased at the rate of $20.00,17.16,21.43,4.53,22.90$, $12.83,11.76$ and 7.68 per cent per annum, respectively. However, the compound growth rate of total area under Banswara district had increased to the tune of 21.25 per cent per annum.

\section{Compound Growth Rate of Production of Rabi Maize in Banswara District of Rajasthan}

The compound growth rate for production of rabi maize in all tehsils of Banswara were 
found positive except for Gangadtalai tehsil during the study period. The growth rate in different tehsils of the district ranged from as low as -5.24 per cent per annum in Gangadtalai to as high as 36.01 per cent per annum in Bagidora tehsil over the years. Similarly, the growth rate of production in Garhi, Banswara, Ghatol, Kushalgarh, Sajjangarh, Anandpuri, Chhotisarvan,
Abapura and Ganoda tehsils had increased at a rate of $34.53,33.20,27.46,13.76,2.35$, $28.76,18.05,16.70$ and 13.35 per cent per annum respectively, during the study period. However, the compound annual growth rate of production for the Banswara district as a whole, was registered at 37.69 per cent per annum.

Table.1 Annual compound growth rates in area, production and yield of rabi maize in Banswara district of Rajasthan (2007-08 to 2017-18) (per cent)

\begin{tabular}{|l|l|c|c|c|}
\hline S.No. & Tehsil & Area & Production & Yield \\
\hline $\mathbf{1 .}$ & Bagidora & 23.80 & 36.01 & 12.66 \\
\hline $\mathbf{2 .}$ & Garhi & 20.00 & 34.53 & 7.50 \\
\hline $\mathbf{3 .}$ & Banswara & 17.17 & 33.20 & 8.91 \\
\hline $\mathbf{4 .}$ & Ghatol & 21.43 & 27.46 & 5.25 \\
\hline $\mathbf{5 .}$ & Kushalgarh & 4.53 & 13.76 & 11.91 \\
\hline $\mathbf{6 .}$ & Sajjangarh & -5.00 & 2.35 & 7.75 \\
\hline $\mathbf{7 .}$ & Anandpuri & 22.90 & 28.76 & 4.76 \\
\hline $\mathbf{8 .}$ & Chhotisarvan & 12.83 & 18.05 & 4.63 \\
\hline $\mathbf{9 .}$ & Gangadtalai & -10.34 & -5.24 & 5.69 \\
\hline $\mathbf{1 0 .}$ & Aabapura & 11.76 & 16.70 & 4.41 \\
\hline $\mathbf{1 1 .}$ & Ganoda & 7.68 & 13.35 & 5.27 \\
\hline & Banswara district & 21.25 & 37.69 & 13.55 \\
\hline & (S) Aura & & & \\
\hline
\end{tabular}

(Source: Author's calculation based on secondary data)

Table.2 Instability in Area of Rabi Maize in Banswara District (2007-08 to 2017-18)

\begin{tabular}{|l|c|c|c|}
\hline Tehsil & Mean (ha) & S.D. (ha) & C.V. (per cent) \\
\hline Bagidora & 1446.45 & 843.18 & 58.29 \\
\hline Garhi & 533.27 & 379.06 & 71.08 \\
\hline Banswara & 2443.72 & 1605.59 & 65.70 \\
\hline Ghatol & 2402.18 & 1647.10 & 68.56 \\
\hline Kushalgarh & 633.90 & 253.60 & 40.00 \\
\hline Sajjangarh & 827.5 & 175.76 & 21.24 \\
\hline Anandpuri & 241.83 & 85.38 & 35.30 \\
\hline Chhotisarvan & 40.33 & 8.82 & 21.87 \\
\hline Gangadtalai & 105.2 & 21.92 & 20.84 \\
\hline Aabapura & 76.4 & 15.07 & 19.73 \\
\hline Ganoda & 1033 & 140.38 & 13.58 \\
\hline Banswara & 8758.8 & 5225.8 & 59.66 \\
\hline District & & & \\
\hline \multicolumn{2}{|c|}{ (Source: Author's calculation based on secondary data) } \\
\end{tabular}


Table.3 Instability in Production of Rabi Maize in Banswara District (2007-08 to 2017-18)

\begin{tabular}{|l|c|c|c|}
\hline Tehsil & Mean (Qtls) & S.D. (Qtls) & C.V. (per cent) \\
\hline Bagidora & 7149.77 & 4073.50 & 56.97 \\
\hline Garhi & 2338.22 & 2361.73 & 101.00 \\
\hline Banswara & 10070.22 & 7088.83 & 70.39 \\
\hline Ghatol & 10780.22 & 9413.37 & 87.32 \\
\hline Kushalgarh & 2642.33 & 1086.58 & 41.12 \\
\hline Sajjangarh & 3848.5 & 649.87 & 16.88 \\
\hline Anandpuri & 1138.66 & 506.93 & 44.51 \\
\hline Chhotisarvan & 186.5 & 56.84 & 30.48 \\
\hline Gangadtalai & 471 & 55.41 & 11.76 \\
\hline Aabapura & 361.4 & 106.31 & 29.41 \\
\hline Ganoda & 4800.2 & 1206.1 & 25.12 \\
\hline Banswara district & 34012.45 & 27523.30 & 80.90 \\
\hline \multicolumn{2}{|l|}{ (Source: Author's calculation based on secondary data) } \\
\hline
\end{tabular}

Table.4 Instability in Yield of Rabi Maize in Banswara District (2007-08 to 2017-18)

\begin{tabular}{|l|c|c|c|}
\hline Tehsil & Mean $(\mathbf{Q t} / \mathbf{h a})$ & S.D. $(\mathbf{Q t} / \mathbf{h a})$ & C.V. (per cent) \\
\hline Bagidora & 38.68 & 11.75 & 30.39 \\
\hline Garhi & 34.41 & 16.17 & 46.99 \\
\hline Banswara & 35.35 & 9.60 & 27.17 \\
\hline Ghatol & 35.55 & 13.44 & 37.80 \\
\hline Kushalgarh & 39.67 & 11.57 & 29.00 \\
\hline Sajjangarh & 47.16 & 6.79 & 14.40 \\
\hline Anandpuri & 45.67 & 5.71 & 12.52 \\
\hline Chhotisarvan & 45.52 & 5.57 & 12.24 \\
\hline Gangadtalai & 45.6 & 6.26 & 13.74 \\
\hline Aabapura & 46.59 & 5.50 & 11.80 \\
\hline Ganoda & 45.92 & 5.93 & 12.92 \\
\hline Banswara district & 33.08 & 12.91 & 39.02 \\
\hline
\end{tabular}

(Source: Author's calculation based on secondary data)

Compound Growth Rate of Yield of Rabi Maize in Banswara District of Rajasthan

Table 1 indicates that the compound growth rates for yield of rabi maize were positive in all the tehsils of Banswara district for the period under study. The growth rate of yield was found to be lowest in Abapura tehsil (4.41 per cent per annum) whereas, it was found to be highest in Bagidora tehsil (12.66 per cent per annum). Yield of rabi maize in
Garhi, Banswara, Ghatol, Kushalgarh, Sajjangarh, Anandpuri, Chhotisarvan, Gangadtalai, and Ganoda tehsils have registered a positive growth rate of 7.50, 8.91, $5.25,11.91,7.75,4.76,4.63,5.69$ and 5.27 per cent per annum, respectively. Similarly, the compound growth rate of yield under rabi maize in Banswara district registered a positive growth rate of 13.55 per cent per annum. 
Thus, both the area and yield of rabi maize had contributed towards the growth and production of rabi maize in Banswara district. Bagidora tehsil was found to be the major rabi maize growing area in Banswara district having the highest growth rates of area, production and yield as compared to other tehsils. This was mainly due to awareness of farmer about the knowledge and availability of improved seed, technical guidance of farmers with solutions of various socioeconomic constraints, proper seed storage and adequate irrigation and marketing facilities in the area.

\section{Inter Year Instability in Area, Production and Yield of Rabi Maize}

Instability is a major problem of every sector of economy. Agriculture sector is prone to risk and uncertainties, which in turn makes it necessary to study the temporal growth pattern of area, production and yield of crops coupled with instability to give a more realistic picture about agricultural parameters in the past. It is important to have quantitative measures of instability, so that the seriousness of the problem can be assessed objectively. The degree of instability in area, production and yield of rabi maize crop were measured by using coefficient of variation, which measures the absolute variation in the set of data. The higher is the value of coefficient of variation, the greater is the instability and vice versa. As far as the inter year extent of variation in different parameters of crop is concerned, the coefficient of variation of original parameters data may include trend, cyclical variation, seasonal variation and irregular or random variation. For crosssectional data, the simple coefficient of variation can give a fairly good idea of extent of instability in the set of data. However, in time series data the simple coefficient of variation may be misleading, since trend positive or negative, generally exist in time series data. Therefore, coefficient of variation (C.V.) after eliminating the trend effect of area, production and yield may give a better measure about the extent of instability in time series data. The coefficient of variation values for original data values in terms of area, production and yield of rabi maize crop after eliminating the trend are given in Table 2, 3 and 4 respectively.

\section{Inter Year Instability in Area}

The results of instability in area under rabi maize measured in terms of coefficients of variation (C.V.) were presented in Table 2. There was lot of instability in area under rabi maize in all the tehsils of Banswara district during the study period (2007-08 to 2017-18). The coefficient of variation estimated for all the tehsils were very high ranging from 13.58 per cent in Ganoda tehsil to as high as 71.08 per cent in Garhi tehsil. In Garhi tehsil, the mean area under rabi maize was only 533 hectares so year to year variations in area was seen due to changes in agro-climatic variations. On the other hand, mean area of 1033 hectares was found to be under rabi maize cultivation in Ganoda tehsil. The low instability in area in the tehsil is mainly due to the adequate irrigation facilities available in the area due to the presence of Mahi Sagar Bajaj Dam. However, the coefficient of variation for Banswara district as a whole was found to be as high as 59.66 per cent having 8758.8 hectares of mean area under rabi maize cultivation.

\section{Inter Year Instability in Production}

Production of rabi maize was highly instable in different tehsils of Banswara district (Table 3 ). The coefficient of variation was found to be lowest in Gangadtalai tehsil (11.76 per cent) due to very less area covered under the crop. The mean production of rabi maize in Gangadtalai tehsil was only 471 quintals 
during the period 2007-08 to 2017-18. Also, the growth rate of area under the crop was found to be negative in the tehsil over the study period. On the other hand, the production of rabi maize was found to be highly unstable in Garhi tehsil during the study period with coefficient of variation registered as high as 101 per cent. The tehsil had a mean production of 2338.22 quintals and only 533.27 hectares of mean area under rabi maize production during the study period. The total mean production of rabi maize in the Banswara district was found to be highly unstable. The coefficient of variation of variation for the Banswara district was found to be 80.90 per cent and a total of 34012.45 quintals production had been recorded during the study period. This is probably due to high instability in production among the various tehsils owing to the irregular patterns of rainfall and lack of adequate irrigation facilities in some tehsils of the district.

\section{Inter Year Instability in Yield}

There was a lot of instability in the productivity of rabi maize among the various tehsils of Banswara district (Table 4). Aabapura tehsil was found to have the least instability in the crop yield having coefficient of variation as low as 11.80 per cent with average mean yield of as high as 46.59 quintals per hectares during the study period. This was probably due to the high yielding varieties being grown in the region. Besides having the highest instability in area and production of rabi maize, Garhi tehsil had recorded the highest instability in the crop yield as well. The coefficient of variation for the tehsil was found to be as high as 46.99 per cent for the period under study. Whereas, the mean yield under rabi maize in the area was found to be 34.41 quintals per hectare. For the Banswara district as a whole, the mean yield of the crop was found to be 3308.3 quintals per hectare with coefficient of variation recorded at 39.02 per cent.

It can be concluded from the above discussion that an increasing trend was observed in area, production and productivity of rabi maize in Banswara district for the period 2007-08 to 2017-18. The compound annual growth rate of total area under Banswara district had been increased to the tune of 21.25 per cent during the study period. It was observed to be positive for all the tehsils of Banswara except for Sajjangarh and Gangadtalai where it declined at a significant rate of 10.34 and 5.00 per cent per annum. Similarly, the other tehsils of Banswara district viz., Garhi, Banswara, Ghatol, Kushalgarh, Anandpuri, Chhotisarvan, Aabapura and Ganoda had registered a positive growth rate of 20.00 , $17.16,21.43,4.53,22.90,12.83,11.76$ and 7.68 per cent per annum, respectively. Similarly, the production of rabi maize in Banswara district registered a significantly positive growth rate of 37.69 per cent per annum. The compound growth rate for production of rabi maize in all tehsils of Banswara had been positive except for Gangadtalai (-5.24 per cent per annum). Bagidora registered maximum growth rate of 36.01 per cent per annum among all tehsils of Banswara. The production of Garhi, Banswara, Ghatol, Kushalgarh, Sajjangarh, Anandpuri, Chhotisarvan, Abapura and Ganoda tehsils increased at a rate of 34.53, $33.20,27.46,13.76,2.35,28.76,18.05,16.70$ and 13.35 per cent per annum respectively, during the same period. Whereas, the yield of rabi maize crop was observed to be positive in all the tehsils for the period under study. Yield of rabi maize in Abapura, Garhi, Banswara, Ghatol, Kushalgarh, Sajjangarh, Anandpuri, Chhotisarvan, Gangadtalai, Ganoda and Bagidora recorded a positive growth rate of $4.41,7.50,8.91,5.25,11.91$, $7.75,4.76,4.63,5.69,5.27$ and 12.66 per cent per annum, respectively. The total yield of 
Banswara district registered an overall growth rate of 13.55 per cent per annum. The positive growth rates in area, production and productivity of rabi maize indicated that the environmental factors were in support of increased production of rabi maize in Banswara district, implying that the prospects of rabi maize in the study area were good.

\section{References}

Acharya, S.P., Basavaraja, H., Kunnal, L. B., Mahajanashetti, S. B. and Bhat, A. R. S. 2012. Growth in area, production and productivity of major crops in Karnataka. Karnataka Journal of Agricultural Sciences, 25 (4): 431-436.

Ayalew, B. and Sekar, I. 2016. Trends and regional disparity of maize production in India. Journal of Development and Agricultural Economics. 8 (9): 193-199.

Dey, A., Dinesh and Rashmi. 2020. Rice and wheat production in India: An overtime study on growth and instability. Journal of Pharmacognosy and Phytochemistry, 9 (2): 158-161.

Eswaran, N. and Revathi, R. 2017. A study on growth and performance of food grains in India with special reference to maize. Journal of Humanities and Social Science, 22 (12): 28-36. instability in area, production, yield and price of rice in India. Social Change and Development, 15 (2): 46-66.

Kachroo, J., Sharma, A. and Bhat, A. 2013. Study on growth and instability of maize in Jammu and Kashmir. Economic Affairs. 58 (1): 21-28.

Paltasingh, K. R. and Goyari, P. 2013. Analyzing growth and instability in subsistence agriculture of Odisha: Evidence from major crops. Agricultural Economics Research Review, 26: 67-78.

Reddy, B. S., Naidu, G. V. and Reddy, M. N. 2015. Trends in food crops and nonfood crops in India. International Journal of Current Innovation Research, 1 (9): 207-212.

Sahu, P. K. and Mishra, P. 2014. Instability in production scenario of maize in India and forecasting using ARIMA model. International Journal of Agriculture and Statistical Sciences. 10 (2): 425435.

Singh, R. K. P. and Ranjan, K.P. 1998. Growth and instability in production of principal foodgrain crops: A case of backward economy. Bangladesh Journal of Agricultural Economics, 21 (1): 1-20.

Jain, A. 2018. Analysis of growth and

\section{How to cite this article:}

Urmila, Latika Sharma and Deepali. 2020. Growth Performance and Instability Analysis of Rabi Maize in Banswara District of Rajasthan. Int.J.Curr.Microbiol.App.Sci. 9(09): 717-725. doi: https://doi.org/10.20546/ijcmas.2020.909.091 